\title{
The Rise and Decline of Cocoa Production and its Economic Implication on the Cocoa Farmers in Ondo State, Nigeria
}

\author{
Oyewale, Peter Oluwaseun (Ph.D) \\ Department of History and International Studies, \\ Faculty of Arts, Ekiti State University, \\ Ado-Ekiti, Nigeria \\ Email: oluwaseun.oyewale@eksu.edu.ng \\ Phone no: +2348034354343
}

\begin{abstract}
This project is concerned with the economic implication of the rise and decline of cocoa production on the people of Ondo State, Nigeria. A lot of scholarly works exist on cocoa industry in the study area, but to the best of my knowledge, this is the first work to examine the rise and decline of cocoa and how it has affected the life of people of Ondo Sate. The Post independence cocoa boom of 1960s brought a new hope into the life of cocoa farmers in Ondo State, while the period 1980 was historical in the cocoa sector of the state. It was historic in the sense that the period coincided with the mass production and exploration of crude oil in Nigeria. This development had negative economic implication on the people of the state. Because of the large population of the state, three cocoa settlements were randomly selected for this study i.e Ile-Oluji, Idanre and Bagbe. These settlements were selected because they were known to be the largest producer of cocoa in the state.

The methodology adopted for this work is historical approach. Hence, the study is based on primary and secondary sources. The primary sources comprise of oral interview, newspapers, government gazettes, while relevant books were consulted as useful secondary sources.

The study conclude that cocoa was an important cash crop which brought positive changes into the life of people and government of Ondo state before the exploration and production of crude oil in commercial quantities in Nigeria.
\end{abstract}

Keywords: Cocoa, Production, Farmer, Exploration, Industry, Settlement

\section{INTRODUCTION}

Ondo State is one of the prominent states in Southwestern Nigeria. The state is blessed with both human and natural resources. The ethnic composition of Ondo state is largely from Yoruba sub-groups of Akoko, Akure, Okitipupa, Ilaje, Ondo and Owo People. Ijaw such as Apoi and Arogbo population inhabit the coastal areas, while a sizable number of Ondo people speak a variant of Yoruba language similar to Ife dialect reside in Oke-Igbo. Agriculture remains the main occupation of people of Ondo state during pre-colonial to post-colonial era. In the pre-colonial period, agriculture was the most important source of wealth in Ondo State before the colonial era. Prior tho the advent of Europeans to the soil of Nigeria with their 
massive demand for tropical raw materials, Ondo state farmers engaged in food crops production combined with palm oil processing mainly for home and local consumption.

The introduction of cocoa into Ondo state economy marked a significant development in the agricultural sector of the state. Cocoa was probably Nigeria's most profitable cash crop during the colonial period. From the colonial period up to about 1970s, cocoa played a dominant role in Nigeria economy. It was also central to the economic life of the majority of Nigerian rural population which constituted about $60 \%$ of the total population. ${ }^{1}$ Nigeria was the second leading producer of cocoa in the world after Ghana and the world's leading producer of palm oil and groundnut during the colonial period. At the early stage of its introduction, cocoa had to compete with other existing forest products particularly palm produce. Cocoa, unlike palm tree is not indigenous to Nigeria. ${ }^{2}$ At the early stage of its introduction, most farmers in southwestern Nigeria especially in Ondo state were mainly produced food crops for consumption and commercial purposes. But by 1920 s, in spite of the long and intensive labour required in the growing of cocoa most farmers in the southwestern Nigeria preferred it to the older export crops such kolanut, cocoa coffee, cotton etc. Consequently, whenever suitable land was available, farmers concentrated on cocoa cultivation. In some districts, farmers grew barely enough food crops to feed their immediate family members as it was generally believe that, no food crop farmer could prosper like cocoa farmers. This belief brought about crop diversification that prompted food crop farmers to shift to cocoa production. ${ }^{3}$ In fact, with encouraging prices, the farmers became so optimistic about the continued prosperity of cocoa relative to other cash crops, even during years of declining prices, farmers still fully concentrated on the plantation of cocoa. ${ }^{4}$

The expansion of cocoa output occurred through an extensive pattern of cultivation which involved the opening up of previously uncultivated finest area. One of the factor responsible for mass production of cocoa in Ondo state was the fact that the cocoa farmers were able to draw on a variety of institutional mechanism. ${ }^{5}$ Cocoa farmers were encouraged to produce because of the option of purchasing the material needed for the growing of cocoa either in cash or credit or of acquiring them through their participation in various "noneconomic" institutions or relationships, including the extended family or the ethnic community which economists were long described as an impediment to economic growth and change. 
It could be rightly said that the existence of land tenure system encourage farmers to consentrate to produce. Suitable land was readily available for growing of cocoa in the region. The growing demand for cocoa had led to a number of changes in the relationship between land owners and land users in the cocoa farming areas in the state. It has been established that most cocoa farmers whether those whose farms were within the border of their city-state or those who obtain them elsewhere, did not own the land they farmed on. Rather, they obtain permission to farm there from someone, usually the head of the lineage which claims "ownership" of the land in return for some form of acknowledgements of the grantor's control over the land and agreement to accept the authority of local leaders. ${ }^{6}$ But in some cases some of the cocoa farmers got their farmland through inheritance either from their late parent of husband. ${ }^{7}$

Cocoa has contributed immensely to the economic transformation of Ondo state during the colonial era. It made a significant contribution in terms of the volume of production, foreign exchange earning capacity, and income generator to Nigeria economy at large. ${ }^{8}$ In terms of foreign exchange earnings, no single agricultural export commodity has earned more than cocoa for Nigeria. ${ }^{9}$ Also in the area of employment generation, the cocoa sub-sector provides both direct and indirect employment to the region. Directly or indirectly, the product boasted the economy of the state.

\section{HISTORICAL DEVELOPMENT OF COCOA IN ONDO STATE}

The introduction of cocoa seeds into Nigeria marked a great development in the agricultural sector of the Nation. Cocoa is a community crop produced in fourteen states. In

Nigeria i.e. (1) Abia (2) Adamawa (3) Akwa-Ibom (4) Cross River (5) Delta (6) Edo (7) Ekiti (8) Kogi (9) Kwara (10) Ogun (11) Ondo (12) Osun(13) Oyo (14) Taraba while Ondo State remain the largest producer of cocoa closely followed by Cross River, Osun, Oyo and Ogun State. ${ }^{10}$

Historically, cocoa is a plant indigenous to the tropical rain forests south and central America. It discovery by Spain in the sixteenth century brought the community to Europe which led to the emergence of the chocolate industry. ${ }^{11}$ By the nineteenth century, other parts of the world were introduced to its cultivation. The process started in West Africa which received the crop from Brazil. The Island of Sao Tome and Principe along with Fernando PO emerged as early places for the cultivation of cocoa in Africa. ${ }^{12}$ In the early, nineteenth 
century, African production began to overtake that of Americans as early as 1902, when Nigerian alone was producing over 100,000 tonnes per year, a volume that was unprecedented for any particular country of the time. ${ }^{13}$

Beginning of the mid nineteenth century, cocoa was introduced on a large scale in Nigeria especially in Ondo State, the area inhabited prominently by the Yoruba people. ${ }^{14}$ It was introduced to Western Nigeria in the late century. The earliest cocoa farmers in the Region were established by Lagos merchants and traders who took up farming when their trading and commercial activities were no more yielding the desired dividends. Majority of these cocoa farmer were established near Agege and Otta in the present Lagos and Ogun states respectively. While some Ondo planted farms near their trading communities in Southern Ondo. ${ }^{15}$ They combined farming with their trading activities and some of these farms were established at various ports along the routes from Lagos to the interior, such as Ajebandele, Aiye Oba, ogudu etc.

The cultivation of coca firmly took root in Ondo region in the last quarter of the nineteenth century which was believed to have been introduced through some Lagos traders who were already familiar with the demand for European market. ${ }^{16}$ These traders later became planters and started cocoa cultivation at Ijan village near Agege on the outskirts of Lagos where cocoa planting and the activities of African church went hand in hand. The activities of colonial government together with members of African Church and the missionary bodies in the spread of Cocoa in Ondostate cannot be overemphasized. This is because individuals in the church used their influence to spread the knowledge of cocoa cultivation in their areas of location. ${ }^{17}$ Rev. Phillips, one of the propagators of cocoa cultivation persistently urged his church members to take up cocoa cultivation. He devoted his sermons on several occasions to the gospel of cocoa and coffee growing. ${ }^{18}$ The major theme of his sermon was that the members should take up farm work, plant and produce cocoa so as to be able to help the church financially.

Although, the adoption and planting of cocoa was initially slow, by the first decade of the $20^{\text {th }}$ century, cocoa had become an important export crop in Nigeria. However, as people realized the economic importance of cocoa and heard about the prosperity it had brought to the people of Gold Coast, it spread quickly to some part of Yorubaland most especially Ondo state, which is today known to be the major producer of cocoa in Nigeria. ${ }^{19}$ The introduction 
of cocoa in Ondo state marked a significant development in economic structure of the state. At the initial state, the early cocoa farmers in Ondo State relied on their own efforts to embark on cocoa growing assisted whenever possible by their immediate families and occasionally by other relatives. Many of the cocoa farmers in the area married many wives and gave birth to many children for the purpose of acquiring the much needed labour for their cocoa farm since hired labourers were relatively scarce at the inception. ${ }^{20}$

The expansion of cocoa industry in Ondo State hampered the development of the other

capital export crops. ${ }^{21}$ This was so, because, in an attempt to gain from cocoa boom of the 1950s, most farmers in the state cultivate cocoa on most of the available land with little or none reserved for cultivation of other cash crops. This situation was so worrisome in that many farmers completely shifted to cocoa production. This development led to the planting of cocoa in the neighouring towns of Ondo state like Ife, Gbongan and Ekitiland.

\section{FACTORS THAT AIDED THE PRODUCTION OF COCOA IN ONDO STATE}

Generally speaking, the introduction of cocoa into the economy of people of Ondo state marked a significant development in both the farmers and the entire state. At the initial stage, the production was slow and low, the peasant farmers were reluctant to engage in the production largely because of the ignorance of its prospects, the gestation period facilities and above all because it had no domestic use. ${ }^{22}$ But the encouragement given to cocoa production by the colonial government gave new hope to cocoa farmers. This later led to mass production of cocoa. In the state 23

Generally speaking, with the construction of new access road to rural area and other incentives provided by the price index, more and more peasant farmers got involved in cocoa cultivator. The purchase and export of cocoa beans was dominated by foreign firms who gave loan to both farmers and middlemen who purchased from producers. ${ }^{24}$

Also the land of Ondo is relatively good soil with no large scale soil erosion or the widespread sheet and gully erosions common in part of the northern states of Nigeria. A large part of the region consists of fertile soil exceptionally good for planting of cocoa. ${ }^{25}$ Equally, the system of land tenure and land use generally ensured that a great majority of young men have land to engage themselves as a cocoa farmers. ${ }^{26}$ The encouragement given to cocoa farmers by the colonial government motivated farmers to produce more of cocoa in Ondo state. Government initiated a lot of policies to tackle a wide range of issues in promoting the 
quality of cocoa in Nigeria, most especially in Ondo State. Right from the Colonial period, authorities within Nigeria have been striving and formulating policies to improve the quality and quantity of cocoa, so that it will command world respect and return the highest possible price in widely distributed export market. ${ }^{27}$

The interest of colonial government in agriculture especially in cocoa and production of other cash crops was high because of the need for raw materials and agricultural products necessitated by the industrial revolution in Europe. Although before 1900, colonial government did not show keen interest in agriculture, while there were many decisions of the colonial state in regard to land tenure, fiscal and other financial matters impinging on agriculture. $^{28}$

However, agricultural policies throughout most of the colonial period was consistent in the emphasis placed on export crops, the neglect of local, social and economic conditions and the neglect of food sector. In other words, colonial agricultural policies were synonymous with efforts to increase the export of primary agricultural products, mainly to Britain. But the contradiction between European economic interest and the best interest of local farmers was evident from the neglect of subsistence agriculture through the pursuit of cash crop economy especially cocoa. This view was corroborated by Olomola's view who opined that the colonial government promoted and encouraged cocoa farmers to continue to produce cocoa to the extent that during the war time when it was difficult to sell cocoa outside the country, colonial government continued to buy cocoa from local farmers and turned into warehouse. The essence of doing this was to encourage cocoa farmers to continue to produce. ${ }^{29}$ All these factors served as an encouragement to cocoa farmers in Ondo State and other producing states in Nigeria to continue to produce and planting of more cocoa seed.

\section{THE ERA OF COCOA BOOM AND ITS EFFECT ON COCOA FARMERS IN ONDO STATE}

The role of cocoa in the economic development of Ondo State has been a notable one and had probably made a more important contribution than any other agricultural commodity. ${ }^{30}$ Because of the economic importance of cocoa to both the people of Ondo State and colonial government, the colonial government took a bold step to distribute cocoa seeds to other places like Ibadan and Abeokuta. This led to the establishment of the first large scale plantation in Ibadan province. $^{31}$ 
Cocoa production made a significant impact on the economic life of people of Ondo State. It generated employment for many household. The industry offers large opportunities in generating rural employment. It is an important source of government revenue and this industry was a main source of foreign exchange earner from Ondo State government until the commercialization of petroleum in the late $1970 \mathrm{~s} .^{32}$

The effect of cocoa was also felt by the land owners. The increase in the area of land under cocoa cultivation brought about two basic changes in the economic and traditional structure of the state. There was a change in the Ondocustom of land tenure and cultivation. The general acceptability of cocoa by Ondo state farmers forced tenure arrangement to begin to alter from communal forms of ownership towards those of individual property right adjustable through purchase and sale. Also, the massive cultivation of cocoa led to changes in the pre-existing pattern of labour employment. The increasing demand for labour in Ondo state contributed to the overall development of a different pattern of labour migration to Ondo state. $^{33}$

The massive cultivation of cocoa in Ondo state brought about economic change and reduces the level of crime in the society. Many of the youth who engaged in thuggery took the advantage of cocoa and many of them worked in cocoa farms as labourers while some who had access to land became cocoa farmers. ${ }^{34}$ Cocoa attracted many people into the region. This had very good implication of the economic development of Ondo people because as population grows, traders also benefited as they experience quick turnover. ${ }^{35}$

It is equally important to note that the prosperity of cocoa had a positive impact on the Ondo farmers. The role that cocoa played in the development of Ondo economy in the provision of rising income for cocoa farmers cannot be overemphasized. The increased incomes came mainly as a result of rising trend in world prices. ${ }^{36}$ The boom years for cocoa came after the Second World War when there was an increase demand for cocoa with virtually unchanged world supply. ${ }^{37}$ This was possible because of the encouragement given to coca farmers by the colonial government. The economic benefit of cocoa cut across individuals, communities and the government. As it has been explained earlier, the production had greatly affected the idea of land ownership in the region. The increased demand for good cocoa land made the latter a herculean task to come by because of its high economic value. ${ }^{38}$ 
The spread of cocoa cultivation and the resultant commercialization of exchange of various right to land, therefore, opened up new economic awareness and opportunities to families and individuals who had or could establish control over any uncultivated forest land in Ondo state. A transition from subsistence economy was the increase in people's income which cocoa provided. ${ }^{39}$ Some of the people interviewed adduced their success to the plantation and production of cocoa.

It is important to note that, the people of Ondo State has been benefited in the cocoa boom of 1970s, this manifested in the people's life style, building styles, pottery, purchasing power and increase in standard of living. During the cocoa boom, farmers had enough money to purchase such valuable items like cars, motorcycles, bicycles, radio, television set. ${ }^{40}$ Besides these, durable goods most cocoa farmers spend a large of their income on capital project such as building new houses, renovation of old ones and education of their children. Oral interview with Pa. Akinola, a seasoned cocoa farmer opined that most cocoa farmers sent their children abroad for further studies. Some of these farmer's children who had opportunity to travel abroad came back to establish commercial ventures in their various towns such as petrol stations, hotels, private schools as well as given out scholarship to deserving children of their communities. ${ }^{41}$

\section{THE DECLINE OF COCOA AND ITS EFFECT ON THE ECONOMY OF ONDO STATE}

Prior to the advent of crude oil economy, Nigerian government heavily depended on cocoa which was known to be an important cash crop among the people of Ondo State. It was the major source of revenue to both government, cocoa farmers and merchants. The money realized from cocoa was used for implementing first development plan, 1962-1968. ${ }^{42}$ Before the emergence of crude oil into Nigeria economy, the people of Ondo State witnessed an aggressive and mass production of cocoa. Statistics revealed that over $60 \%$ of Ondo State population engaged in the production of cocoa, that is to say, agriculture was the major employer of labour as we had explained earlier, but the sector has been experiencing great neglect since the advent and commercialization of petroleum in Nigerian economy in the early 1970s. This development had a negative impact on the economy of Ondo State by increasing the rate of unemployment, abject poverty and widespread income inequality that hampered the growth and development of the country at large. ${ }^{43}$ 
Although, it has been argued that, apart from crude oil, there were other factors that could have been responsible for the decline of cocoa economy ranging from level of illiteracy among cocoa farmers inability to apply cocoa insecticide, lack of good and motorable road from farm to city but among these, the advent of petroleum as noted marked the turning point in the annual agricultural growth. The impetus, incentives, and mode of farming were slaughtered on the alter of crude oil exploration. ${ }^{44}$ The argument is that the oil boom year of the 1970s which resulted in the virtual neglect of agricultural sector of the economy and the rural base upon which it operated created a great disequilibrium in the economic opportunities between the rural and urban areas. The oil boom led to rural urban migration to major cities like Lagos, Ibadan, Port Harcourt etc. children of cocoa farmers abandoned their holding and began to migrate to urban centres in search of easier lives. The large resources from oil completely dwarfed contribution from all the other sectors including the agricultural sector and most importantly, rather than attracting investment into agriculture, government decided to focus attentions on urban projects. ${ }^{45}$ This led to the total neglect of rural dwellers where the buld of cocoa is being produced.

The testimonies of cocoa farmers in various cocoa farm settlements in Ondo State gave credence to the government's neglect of cocoa economy. According to Mr. Akinola, a cocoa farmer in Bolorunduro, Ondo State, stated that the oil boom and subsequent exploration of crude oil had a great impact on the socio-economic life of the Ondo people. ${ }^{46}$ Apart from these, cocoa farmers were confronted with numerous problems which militate against the development of cocoa in the area. Some of the problems are listed below:

i. Accessibility to land.

ii. Lack of basic amenities, such as electricity, standard schools for cocoa farmer's children and functioning health care services.

iii. Problems of finance and inability of rural farmers to access credit facilities and loans.

iv. Poor road network.

v. Insufficient good storage and processing facilities like where and how to prevent cocoa seeds are inadequate. ${ }^{47}$

The decline of cocoa production had effect not only on cocoa farmers but also on the cocoa buying agents. Majority of these buying agents had gone to extinction as a result of poor performance of cocoa in the study area. Because of government neglect on this sector, 
one after the other, most of these buying agents folded up as a result of the shift of focus from cocoa as a source of foreign exchange earnings and the non-profitability of cocoa in international market. These and other factors mentioned above had a great negative effect on the economic life of cocoa farmers in Ondo State.

\section{CONCLUSION}

The study is an examination of the rise and decline of cocoa production and its economic implication on cocoa farmers in Ondo state. It has been revealed in this study that since the introduction of cocoa into the economy of Ondo State, the state had witnessed positive changes in her economy, agriculture has been the major occupation that generate wide employment opportunities for the people of the state. The introduction of cocoa in the state had far-reaching consequences on the economic structure of the people of state simply because of the encouragement given to cocoa production by the colonial government and by the various missionaries brought significant changes in the socio-economic history of the people of Ondo state. From about 1920's till the 1970'sincome from cocoa constituted the mainstay of development expenditure by colonial government. Cocoa farmers, merchants, individuals and government benefited from cocoa boom of 1970s. Through money realized from cocoa, cocoa farmers were able to embark on laudable projects and send their children to expensive school.

It has been explained that the exploration and commercialization of crude oil had a far reaching negative effects on cocoa production in Ondo state, the encouragement given to cocoa farmers during the colonial and in post-colonial period were not given during the oil boom, the introduction of crude oil economy had a negative impact on the production of cocoa in ondo state. The advent of petroleum as noted marked the turning point in annual agricultural grouth. The impetus, incentive, and morals of farming were slaughtered on the alter of crude oil exploration. The oil boom led to rural urban migration to major cities which later led to reduction in the population of rural dwellers. Apart from the aforementioned reasons, the limitation placed upon the production of cocoa was due to lack of supporting inputs and scarcity of complimentary inputs placed on farmers that will encourage farmers to produce more such as planting materials 


\section{ENDNOTES}

${ }^{1}$ S.O. Olajide, Economic Survey of Nigeria, Ibadan, Aromolaran Publishing Co. 1976, p. 2.

${ }^{2}$ F.N. Howes, The early introduction of cocoa to West Africa, Op.cit p. 155.

${ }^{3}$ S.S. Berry, Cocoa in Western Nigeria: 1890-1940: A Case Study of Innovation in a Developing Economy PhD Thesis University of Michigan, 1967, pp. 153-158.

${ }^{4}$ S.A. Oni, An Econometric Analysis of the Provincial and Aggregate Response Among Western Nigeria Cocoa farmers PhD Thesis, University of Ibadan, 1971, p. 32.

${ }^{5}$ N. Williamson, Your Research Project. A step by step Guide for the first time Researcher, London, Sage Publication, 2006, p. 272.

${ }^{6}$ P.C. Lloyd Yorubaland Law, Oxford, 1962, p. 64

${ }^{7}$ Ibid.

${ }^{8}$ Familugba

${ }^{9}$ Alamu in Famulugba

${ }^{10}$ The committee was set up by former President OlusegunObasanjo on the $2^{\text {nd }}$ December, 1999.

${ }^{11}$ Food and Agriculture Organization of United Nations (FAO) 2000, World Agriculture toward 2015/2030, Rome.

${ }^{12}$ Ibid

${ }^{13}$ Ibid

${ }^{14}$ P. Lubeck, Nigeria: Impact of the Oil Economy, Indian University Press, 1977, p. 5.

${ }^{15}$ Ibid

${ }^{16}$ A. Olorunfemi, "Effects of War-Time Trade Control on Nigeria Cocoa Traders and Producers, 19391945. A case study of the Hazards of a Dependent Economy".The International Journal of African Historical Studies, Vol. 13 No.4 1980, p. 672.

${ }^{17}$ N.A.I R/G/FA: W. Fowler; A report on the land of the colony District, p. 11.

${ }^{18}$ N.A.I R/G/FA: W. Fowler; A report on the land of the colony District, p. 12.

${ }^{19}$ S.A. Agboola, "Agricultural change in western Nigeria 1850-1910" in I.A. Akinjogbon and S.O. Osoba (eds) Topics on Nigeria Economic and Social History, Ile-Ife, University of Ife Press 1980, pp. 134-135.

${ }^{20} \mathrm{~J}$. Adomako-Sarafoh: The effects of the expulsion of migrants workers on Ghana economy with particular reference to cocoa industry, in Sumir Amin (ed) Modern Migrants in West Africa, Oxford, University Press, 1974, p. 142.

${ }^{21}$ Ibid, p. 143

${ }^{22}$ L.A. Are and DRG Govynne Jones, "Cocoa in West Africa”, Ibadan, University Press, 1973, pp. 2330.

${ }^{23}$ Ibid.

${ }^{24}$ L.K. Opeke, Development of Cocoa Industry on Nigeria, Journal of Agricultural Society of Nigeria, $3^{\text {rd }}$ Edition, 1975, p. 6. 
${ }^{25}$ J. Adams, Remarks on the Country extending from Cape Palma to the River Congo. London, Frank Cass and Co. Ltd. 1966, p. 92.

${ }^{26}$ R.O. Adegboye, An Analysis of Land Tenure structure in some selected areas in Nigeria, Journal of Economic and Social Studies. Vol. VIII No. 2, 1966, pp. 259-268.

${ }^{27}$ S.A. Ogundijo, A Handbook on Cocoa Marketing, Ibadan, Alafas Nigeria Company 1998 p. 27.

${ }^{28}$ O.C. Adesina, A Historical Evaluation of Western Nigerian Government Agricultural Policy 19551966, M.A. Thesis (History). ObafemiAwolowo University, Ile-Ife, 1988, pp. 22-24.

${ }^{29}$ Oral interview with Prof. G.I. Olomola, 70 years, Prof of History, Ajilosun, Ado-Ekiti on $11 / 04 / 2015$.

${ }^{30}$ S.I. Ajayi and T.A. Oyejide, Role of Cocoa in Nigeria's Economic Development" in The Economics of Cocoa Production and Marketing, R.A. Kotey, C. Okali and B.E. Rourke (eds), Institute of Statistical, Social and Economic Research, University of Ghana, Legon 1974, pp. 22-24.

${ }^{31}$ S.S. Berry, Cocoa Custom and Socio-economic Change in Rural Western Nigeria, Oxford University press, 1975 , p. 50.

${ }^{32}$ M.O.K Adegbola and J.O. Abe, Cocoa development programme in Nigeria: paper presented at the technical consultation on agricultural extension methods and techniques for cocoa, Itabuna, Bahia, Brazil, p. 23.

${ }^{33}$ Ibid.

${ }^{34}$ Oral Interview with Mr. SegunOyedokun, 44. Years, a son of cocoa farmer in Edunabon in Osun State on 14/10/2014. See also G.K. Helleiner: Peasant Agriculture, Government, and Economic Growth in Nigeria. The Economic Growth Centre, Yale University.

${ }^{35}$ Ibid.

${ }^{36}$ D. Olatunbosun: Pricing Policy and Supply response in Cocoa production: "The Nigerian case in Kotey et al (eds). The Economics of Cocoa Production and Marketing, Institute of Statistical, Social and Economic Research, Legon, University of Ghana, 1974, pp. 103-110.

${ }^{37}$ Ibid. 120.

${ }^{38}$ Oral interview with Prince Rufus Ayodele, 71 years, at his residence in IdanreOndo State on 23/06/2014.

${ }^{39} \mathrm{O}$. Aribigbola, Origin and Development of Cocoa in Idanre, Ondo state 1880 to present time. A Project Essay Submitted to the Department of History and International Studies, University of AdoEkiti, Ekiti State 2011, pp. 52-53.

${ }^{40}$ A. Alawode, "The Western State Expanded Cocoa Scheme and Farmer", CRIN farmers filled days 20-24, Non Gamberi Experimental station, 1972.

${ }^{41}$ Oral interview with Pa Akinola 71 years, a seasoned Cocoa farmers on 23/10/2015 at his residence in Ogbomoso.

${ }^{42}$ Ogiebor, harvest of Failure, Newswatch, October 5, Lagos, Nigeria 1987, p. 11.

${ }^{43} \mathrm{O}$. Runl, Nigeria is poor because of alternative view publication of change Africa, Africa Centre for Leadership Strategy and Development August, 2010, pp. 28-35.

${ }^{44}$ Ibid.

${ }^{45}$ World Bank Annual Report, Structure of the Nigerian Economy, Ibadan, 1987, p. 12 
${ }^{46}$ Oral Interview with Mr. Akinola, 67 years, a cocoa farmer, Bolarunduro on 20/04/20.

${ }^{47}$ Oral intention with Mrs. Olayede 58 years, a Cocoa Farmers, Ifetedo in Osun State on 23/04/2016. 